\title{
Effects of nitrogen supply on wheat and on soil nitrate
}

\author{
A. ABAD*, A. Michelena, J. Lloveras \\ Centre Universitat de Lleida-IRTA, Av. Rovira Roure 191, 25189 Lleida, Spain
}

(Accepted 11 May 2005)

\begin{abstract}
Field experiments were conducted at two locations during two growing seasons in the Ebro Valley (Spain), to evaluate the effects of $\mathrm{N}$ fertilization on yield and quality of Mediterranean-type wheat in irrigated conditions. Seven $\mathrm{N}$ treatments and a control were investigated. The average grain yields ranged from 2117 to $5551 \mathrm{~kg} \mathrm{ha}^{-1}$ depending on the year and location. Grain protein ranged from 14.25 to $16.9 \%$, and other quality parameters such as the dough strength (W) also varied with year and location, confirming the suitability of Mediterranean-type wheat and the climate for the production of good bread-making quality wheat. However, grain yields are normally low and both yields and quality can be greatly affected by the variability of this type of climate, even under irrigation. Under these conditions, grain yield increases were mainly due to an increase in the number of grains per $\mathrm{m}^{2}$ without a reduction in the $\mathrm{N}$ content per spike, suggesting that $\mathrm{N}$ in the grain was not source-limited, possibly due to the lower grain yields and relatively high soil nitrate concentrations. In soils with lower initial soil $\mathrm{NO}_{3}^{-} \mathrm{N}$ contents, better grain yields could be achieved by applying a $\mathrm{N}$ fertilizer rate of about $100 \mathrm{~kg} \mathrm{~N} \mathrm{ha}^{-1}$, whereas in soils with high initial $\mathrm{NO}_{3}^{-} \mathrm{N}$ contents, no $\mathrm{N}$ or a maximum rate of $50 \mathrm{~kg} \mathrm{~N} \mathrm{ha}^{-1}$ is needed to obtain a good grain quality, showing the possibility of producing high-quality wheat with a low amount of $\mathrm{N}$ fertilizer and thus increasing the sustainability of the cropping system.
\end{abstract}

soil N / grain yield / crude protein / alveograph / foliar urea / SDS

\section{INTRODUCTION}

Baking quality of wheat is generally related to the protein concentration of the grain (Gate, 1995; Gooding and Davies, 1997), which is determined by genotype and environment, mainly climate, and available $\mathrm{N}$ during the grain-filling period (Gate, 1995; Gooding and Davies, 1997; Lopez-Bellido et al., 1998). A lot of research on the effect of $\mathrm{N}$ on wheat quality, yield and nitrate leaching, has been conducted in many areas of central Northern Europe (Addiscott et al., 1992; Campbell, 1995; Dilz, 1988; Gate 1995; Gooding and Davies, 1997). However, very little information about these factors comes from irrigated Mediterranean regions that normally produce grain of high bread-making quality (Borghi, 1999; Corbellini et al., 1998; Lloveras et al., 2001; Martre et al., 2003). Reports from Mediterranean areas show that they are suitable for the production of high-quality bread-making wheat because the Mediterranean climate, characterized by dry hot summers with mild winters, leads to a shorter grain-filling period, which generally decreases yield and increases protein concentration in the grain (Borghi et al., 1997; Lopez-Bellido et al., 1998).

On the other hand, wheat of good quality needs adequate $\mathrm{N}$ fertilization to satisfy crop demands (Gate, 1995; Gooding and Davies, 1997; Hobbs and Sayre, 2001; Sarandón and Gianibelli, 1992). Generally the total crop $\mathrm{N}$ demand increases with the potential biomass and grain yield. So in an area characterized by great weather variability, like the Mediterranean region, there is a high variability of yield and consequently great difficulty predicting and quantifying $\mathrm{N}$-fertilizer needs.

This difficulty is increased by the variation of soil $\mathrm{N}$ supply and availability, which can be very variable in function of $\mathrm{N}$, balance of the previous crop, and of soil $\mathrm{N}$-mineralization and leaching. In consequence, if the mineral pool of $\mathrm{N}$ in the soil is not managed with precision, we can induce crop $\mathrm{N}$ deficiency and nitrate leaching. To decrease these aleatory variations of yield and grain $\mathrm{N}$ content farmers often use higher rates of $\mathrm{N}$ fertilizer than those required to satisfy the demand, and as a consequence there is an increase in the risk of leaching. To reduce $\mathrm{N}$ losses several reports recommended applications of $\mathrm{N}$ to be postponed to later stages of the growing season, which favors protein build-up in the grain over yield (Sarandón and Gianibelli, 1992), and enhances the bread-making quality of the flour (Altman et al., 1983; Gooding et al., 1991; Gooding and Davies, 1992). However, the effect is a function of the crop $\mathrm{N}$ nutrition status and of the climate conditions, and so this effect is difficult to forecast in Mediterranean areas with high variation in climate (Lloveras et al., 2001). Applications of $\mathrm{N}$ as foliar urea to simultaneously increase the protein content of wheat and reduce risks of nitrate leaching or denitrification have been proposed in regions with little or no water stress during grain filling (Gooding et al., 1991; Gooding and Davies, 1992; Kettlewell and Juggies, 1992; Readman et al., 1997). However, crop responses to urea sprays have been highly variable and no clear benefits have been obtained in Mediterranean

* Corresponding author: aabad1@pie.xtec.es 
areas (Lloveras et al., 2001). In the Mediterranean irrigated areas of the Ebro Valley, wheat is grown in rotation with maize (Zea mays L.) and alfalfa (Medicago sativa L.) mainly as an alternative crop requiring much less water than the summer crops. Despite the limitations of relatively low yield potential, due to the high temperatures during grain filling, farmers try to make wheat cultivation profitable, by applying high $\mathrm{N}$ rates with irrigation. These practices, however, increase environmental pollution (Lloveras et al., 2001) and have been restrained because some areas have been declared vulnerable because of the high levels of nitrates in groundwater.

Finally, the N management and the climatic conditions of the Mediterranean areas, characterized by water deficit and thermal stress during grain filling, may cause large fluctuations in grain yield and grain N concentration (Borghi et al., 1997). Additionally, these variations in protein content can be accompanied by the qualitative variations in proteins: the increase in the quantity of protein per grain leads to an increase in the ratios of stored/metabolic proteins and gliadins/glutenins. So the functional properties of dough can be changed, and the effect depends on the intrinsic genetic potential determined by the polymorphism of stored proteins, essentially of HMW-glutenins (Triboï et al., 2000) (HMW: high molecular weight).

In order to maximize profitability while minimizing pollution, it is important to know the response of the Mediterranean wheat to $\mathrm{N}$ fertilization under irrigation in the Mediterranean climate, and also to know the possible sink/source limitations of the accumulation of $\mathrm{N}$ in the grains..

The main objective of this research was to study the effects of nitrogen fertilization on grain yield, yield components and quality of Mediterranean wheat in two locations with contrasting levels of mineral $\mathrm{N}$ in the soil. By assessing these responses, the local effect of $\mathrm{N}$ on the risk of nitrate pollution was also assessed.

\section{MATERIALS AND METHODS}

Field experiments were conducted under irrigated conditions during two growing seasons (1994-1995 and 1995-1996) at the IRTA (Institut de Recerca i Tecnologia Agroalimentaria) University of Lleida research fields in Torregrossa and Bell.lloc (Ebro Valley, Spain, 4139’ N, 050’ E), on Typic Xerofluvent soils. The experiments were established on 28 December 1994 and 10 February 1996 in Torregrossa and on 7 January 1995 and 23 November 1995 in Bell.lloc. Mean temperatures and mean maximum temperatures, and rainfall for the 1994-95 and 1995-96 wheat-growing seasons are presented in Figure 1.

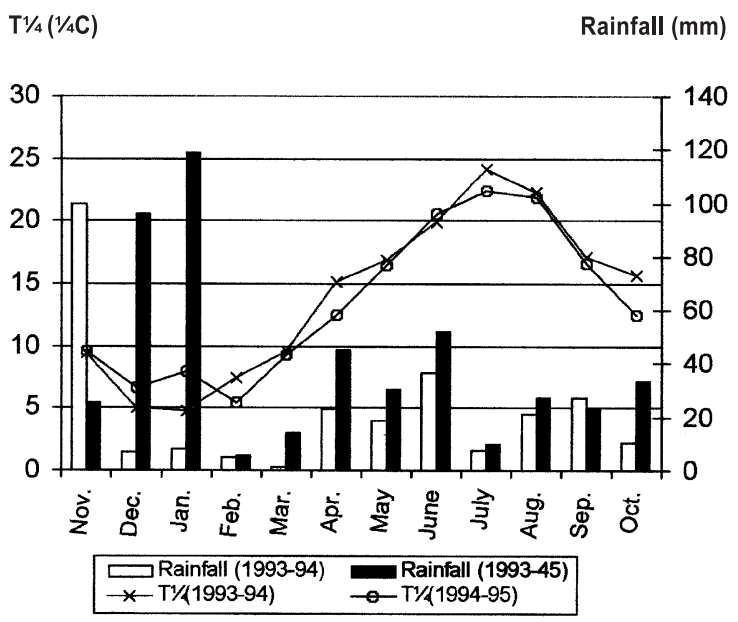

Figure 1. Mean air temperatures and rainfall during the experiments.

In each site, we analyzed the effects on $7 \mathrm{~N}$ treatments and a control on two cultivars of bread wheat (Triticum aestivum L.). No $\mathrm{N}$ was applied in the control. Four of the $\mathrm{N}$ treatments were applied at rates of 50,100, 150 and $200 \mathrm{~kg} \mathrm{ha}^{-1}$. In these treatments $50 \mathrm{~kg} \mathrm{ha}^{-1}$ of $\mathrm{N}$ was applied at seeding and the balance at the end of tillering (growth stage 30, Zadoks et al., 1974). In two other $\mathrm{N}$ treatments of 150 and $200 \mathrm{~kg} \mathrm{ha}^{-1}$, the $\mathrm{N}$ was applied at seeding $\left(50 \mathrm{~kg} \mathrm{ha}^{-1}\right)$, at the flag leaf stage (growth stage 41 , Zadoks et al., 1974) $\left(50 \mathrm{~kg} \mathrm{ha}^{-1}\right.$ as a urea foliar spray) and the balance at the end of tillering. In the last treatment, $200 \mathrm{~kg} \mathrm{~N} \mathrm{ha}^{-1}$ were applied as mentioned in the last procedure, except that at the flag leaf application $\mathrm{N}$ was broadcasted by hand on the soil. The urea solution was applied with a backpack sprayer in water carrier for a total volume of $400 \mathrm{~L} \mathrm{ha}^{-1}$. Minor tip burning was noted after spraying the urea solution, but the plants recovered their green color within a short time. No measurable precipitation was recorded within 48 hours of foliar urea treatments. The cultivars chosen were Rinconada and Bancal. The seeding rates were 450 seeds $\mathrm{m}^{-2}$ with an inter-row spacing of $20 \mathrm{~cm}$ and a plot size of $1.2 \mathrm{~m}$ by $7 \mathrm{~m}$. Crops were irrigated as usual in the region: two times in the spring in March and in April, for a total of about 120$150 \mathrm{~mm}$ of water. The experimental design was a split-plot, with $\mathrm{N}$ fertilizer treatments as main plots, and wheat cultivars as subplots.

The initial soil analyses are presented in Table I and Figure 2. For the determination of soil nitrate, samples were

Table I. Initial soil analyses in Torregrossa and Bell-1loc at three depths at sowing.

\begin{tabular}{|c|c|c|c|c|c|c|}
\hline & \multicolumn{3}{|c|}{ Torregrossa } & \multicolumn{3}{|c|}{ Bell.1loc } \\
\hline & $0-30 \mathrm{~cm}$ & $30-60 \mathrm{~cm}$ & $60-90 \mathrm{~cm}$ & $0-30 \mathrm{~cm}$ & $30-60 \mathrm{~cm}$ & $60-90 \mathrm{~cm}$ \\
\hline $\mathrm{PH}$ & 8.4 & 8.5 & 8.6 & 8.1 & 8.0 & 8.0 \\
\hline Organic matter $\left(\mathrm{g} \mathrm{kg}^{-1}\right)$ & 17 & 9 & 3 & 21 & 14 & 10 \\
\hline Available $\mathrm{P}^{\dagger}\left(\mathrm{mg} \mathrm{kg}^{-1}\right)$ & 41 & 13 & 10 & 44 & 12 & 6 \\
\hline Available $\mathrm{K}^{\ddagger}\left(\mathrm{mg} \mathrm{kg}^{-1}\right)$ & 305 & 148 & 61 & 412 & 254 & 164 \\
\hline
\end{tabular}

$\dagger$ Olsen method, ${ }^{\ddagger}$ Ammonium acetate method. 
Torregrossa

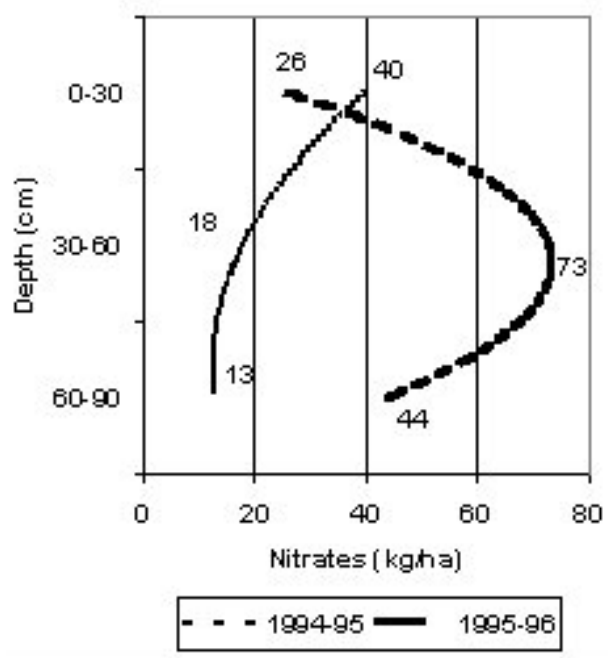

Bell-\|loc

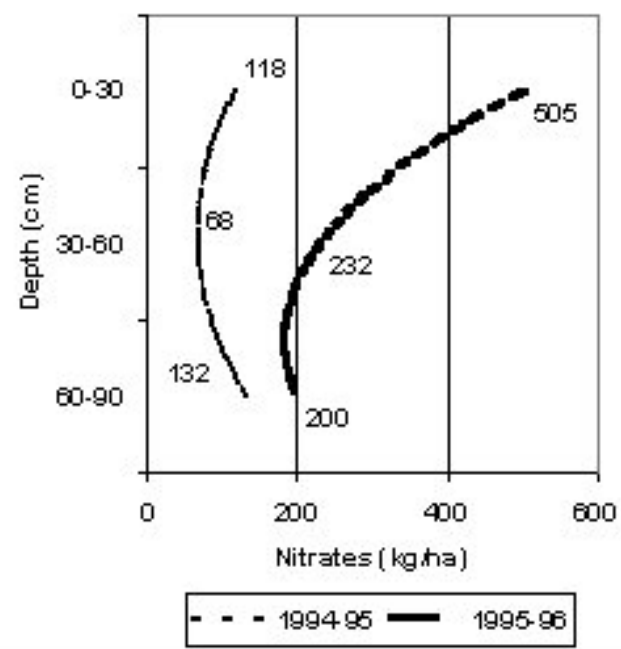

Figure 2. Soil nitrate before sowing at three depths. collected from each plot in autumn before the application of fertilizer and again after harvest. Soil was sampled from 0 to $30 \mathrm{~cm}$, from 30 to $60 \mathrm{~cm}$, and from 60 to $90 \mathrm{~cm}$ using Eijkelkamp cylindrical augers. Soil nitrates were extracted with water, followed by measurement with nitrate test strips and Nitracheck ${ }^{\circledR}$ (Bischoff et al., 1996), and calibrated with the standard procedure (Bremner, 1965). Weeds were controlled as needed with appropriate herbicides.

The number of spikes per unit area was estimated by counting spikes just before harvest along $50-\mathrm{cm}$ sections of two rows in each plot. Fifteen spikes per plot were harvested for the determination of grains per spike and one-thousand kernel weight (TKW). The grain was harvested in late June or July using a 1.5-m-wide Nurserymaster elite (Wintersteiger, Ried, Austria) plot combine. Grain number per $\mathrm{m}^{2}$ was calculated with yield and TKW measured in each subplot.

Grain moisture level was measured (GAC II, Dickey-John, Auburn, Ill, USA) in a 300-g sample from each plot and grain yield adjusted to $14 \%$ moisture. Grain protein percentage was determined by near-infrared reflectance spectroscopy, using a Technicon Infra Analyzer 400 instrument (Bran and Lubbe, Hamburg, Germany), and presented on a dry matter basis. Test weight was obtained with a standard chondrometer. A SDS sedimentation volume test (Peña et al., 1990), a modification of the Axford et al. (1979), was performed as an indicator of protein quality. Bread-making quality was evaluated with the Chopin alveograph according to the ICC Standard Method 121 (International Association for Cereal Science and Technology, 1992). This instrument measures the rheological properties of dough (resistance P, extensibility L and strength W) prepared from flour and water under standardized conditions (Borghi et al., 1997; Gate, 1995). The results were subjected to analysis of variance with the General Linear Model procedure of the Statistical Analysis System and to Pearson correlation coefficients (SAS, 1996). Statistical differences between several treatments were determined by single degree-of-freedom orthogonal contrasts.

\section{RESULTS AND DISCUSSION}

\subsection{Determination of yield}

There was a significant interaction between $\mathrm{N}$ and site for grain yield, and for this reason statistical analysis is presented separately for each site (Tabs. II and III). This interaction was most likely due to the high soil $\mathrm{N}$ content in Bell-lloc that is expected to reduce the response to nitrogen fertilization in this site. Soil N levels before sowing (from 0 to $90 \mathrm{~cm}$ soil depth) were quite different between locations: in Torregrossa, they were $71 \mathrm{~kg} \mathrm{~N} \mathrm{ha}^{-1}$ in 1995 and $143 \mathrm{~kg} \mathrm{~N} \mathrm{ha}^{-1}$ in 1996, compared with 318 and $937 \mathrm{~kg} \mathrm{~N} \mathrm{ha}^{-1}$ in Bell-1loc, for the same years, respectively.

In Torregrossa, $\mathrm{N}$ fertilization increased average grain yields by $31.4 \%$ (Fig. 3) when increasing the $\mathrm{N}$ rates from 0 to $100 \mathrm{~kg} \mathrm{ha}^{-1}$ and only by $4.9 \%$ when increasing from 100 to $200 \mathrm{~kg} \mathrm{~N} \mathrm{ha}^{-1}$. N fertilization significantly increased spikes $\mathrm{m}^{-2}$ and kernels per spike (38.4\% and $35.9 \%$, respectively) and as a consequence increased the number of grains $\mathrm{m}^{-2}(72 \%)$. Onethousand kernel weight (TKW) significantly decreased $(12.2 \%)$ with $\mathrm{N}$ fertilization in Torregrossa. As has been observed in other areas (Frederick and Bauer, 1999) individual grain weight was reduced with increasing yields because there appears to be little relationship between individual kernel weight and grain yield in bread wheat when responding to fertilization.

It has been reported for other areas (Hay and Walker, 1989) that $\mathrm{N}$ fertilization in bread wheat raised spike density at harvest, because of increased tillering. Also, the influence of $\mathrm{N}$ fertilization on the number of kernels per spike is normally positive, but the effect tends to be smaller than that reported for spike density. A very close relationship between grain yield and kernel number $\mathrm{m}^{-2}$ has also normally been reported (Frederick and Bauer, 1999). Our N fertilization research follows a similar trend, which is, yield increases were mainly related to increases in the number of grains $\mathrm{m}^{-2}$. These relationships were mainly observed in Torregrossa. In the other location, the application 
Table II. Yield components (spikes $\mathrm{m}^{-2}$, kernels per spike, 1000 kernel weight and specific weight).

\begin{tabular}{|c|c|c|c|c|c|c|c|c|}
\hline \multirow{3}{*}{$\begin{array}{l}\text { Treatments } \\
\text { and } \\
\text { statistics }\end{array}$} & \multicolumn{2}{|c|}{ Spikes $\mathrm{m}^{-2}$} & \multicolumn{2}{|c|}{$\begin{array}{l}\text { Kernels per } \\
\text { Spike }\end{array}$} & \multicolumn{2}{|c|}{$\begin{array}{l}1000 \text { kernel } \\
\text { weight }(\mathrm{g})\end{array}$} & \multicolumn{2}{|c|}{$\begin{array}{c}\text { Specific weight } \\
\left(\mathrm{kg} \mathrm{Hl}^{-1}\right)\end{array}$} \\
\hline & 1995 & 1996 & 1995 & 1996 & 1995 & 1996 & 1995 & 1996 \\
\hline & \multicolumn{8}{|c|}{ Torregrossa } \\
\hline 0 & 248 & 249 & 26.9 & 21.7 & 50.7 & 45.2 & 85.2 & 84.0 \\
\hline 50 & 256 & 265 & 28.1 & 22.6 & 47.6 & 44.6 & 85.2 & 84.0 \\
\hline 100 & 287 & 282 & 29.0 & 32.9 & 46.1 & 43.1 & 84.5 & 83.1 \\
\hline 150 & 300 & 324 & 29.5 & 31.3 & 46.6 & 36.6 & 84.2 & 81.9 \\
\hline 200 & 331 & 317 & 28.7 & 34.8 & 47.5 & 36.7 & 84.2 & 81.8 \\
\hline 150 uf & 320 & 323 & 28.2 & 34.4 & 46.7 & 40.4 & 85.1 & 82.3 \\
\hline 200 uf & 344 & 342 & 29.5 & 36.4 & 44.2 & 36.4 & 84.4 & 81.2 \\
\hline 200 us & 311 & 375 & 29.9 & 25.2 & 49.8 & 36.2 & 84.3 & 81.5 \\
\hline Average & 300 & 310 & 28.7 & 31.2 & 47.3 & 39.9 & 84.6 & 82.5 \\
\hline \multicolumn{9}{|l|}{ Significance } \\
\hline Nitrogen $(\mathrm{N})$ & NS & $*$ & NS & $* *$ & NS & $* *$ & $*$ & $* *$ \\
\hline Variety (V) & NS & $*$ & NS & $* *$ & $* *$ & $*$ & $* *$ & $* *$ \\
\hline \multirow[t]{2}{*}{$\mathrm{V} \times \mathrm{N}$} & NS & NS & NS & NS & NS & NS & NS & NS \\
\hline & \multicolumn{8}{|c|}{ Bell-1loc } \\
\hline 0 & 311 & 429 & 26.5 & 36.6 & 40.2 & 53.2 & 82.7 & 83.7 \\
\hline 50 & 315 & 429 & 26.5 & 39.2 & 37.7 & 48.6 & 83.5 & 83.4 \\
\hline 100 & 278 & 471 & 25.9 & 38.3 & 39.5 & 50.1 & 82.8 & 83.8 \\
\hline 150 & 283 & 398 & 26.8 & 38.4 & 37.2 & 47.4 & 82.4 & 83.3 \\
\hline 200 & 322 & 496 & 26.2 & 39.0 & 38.3 & 47.1 & 82.4 & 82.9 \\
\hline 150 uf & 308 & 407 & 27.3 & 41.2 & 38.3 & 48.3 & 82.2 & 82.9 \\
\hline 200 uf & 301 & 409 & 25.0 & 40.9 & 40.5 & 50.3 & 82.7 & 83.3 \\
\hline 200 us & 301 & 432 & 24.0 & 38.5 & 38.5 & 46.8 & 82.8 & 83.0 \\
\hline Average & 305 & 434 & 26.0 & 39.0 & 38.7 & 49.0 & 82.7 & 83.3 \\
\hline \multicolumn{9}{|l|}{ Significance } \\
\hline Nitrogen $(\mathrm{N})$ & $* *$ & NS & $* *$ & NS & NS & NS & NS & $* *$ \\
\hline Variety (V) & NS & NS & $*$ & NS & NS & $* *$ & $* *$ & $* *$ \\
\hline $\mathrm{V} \times \mathrm{N}$ & NS & NS & NS & NS & NS & NS & NS & NS \\
\hline
\end{tabular}

In two $\mathrm{N}$ treatments (150 uf and $200 \mathrm{uf}$ ), the $\mathrm{N}$ was applied at seeding $\left(50 \mathrm{~kg} \mathrm{ha}^{-1}\right)$, at the flag leaf stage $\left(50 \mathrm{~kg} \mathrm{ha}^{-1}\right.$ as a urea foliar spray) and the balance at tillering. In the last treatment ( $200 \mathrm{us}$ ), $\mathrm{N}$ was applied as mentioned in the preceding except that the $50 \mathrm{~kg} \mathrm{~N} \mathrm{ha}^{-1}$ flag leaf application was applied to the soil.

*** Significant at the 0.05 and 0.01 probability levels, respectively. NS, not significant at the 0.05 level.

uf: Foliar-applied urea.

us: Soil-applied urea.

of $\mathrm{N}$ fertilizer did not affect grain yields because of the high soil nitrate in this location.

The response obtained in the experiments coincides with general knowledge (Chaney, 1990; Lloveras et al., 2001; Scharf et al., 1993). In soils with low $\mathrm{N}$ content the response to $\mathrm{N}$ fertilization is significant, whereas in soils with a high soil $\mathrm{N}$ content there is no response to $\mathrm{N}$ fertilization. The growing season 1995-1996 had a high precipitation (397 mm), and even in this year there was not a significant response to $\mathrm{N}$ fertilization in Bell-1loc, which suggests that even in a year with a high winter rainfall, the nitrate content of the soil must be considered in $\mathrm{N}$ fertilization recommendations in areas such as those of the Mediterranean regions. In the Ebro Valley, precipitation in winter and at seeding time is normally low; as a consequence, leaching of $\mathrm{N}$ from soil during these periods is rare, so most of the $\mathrm{N}$ remains in the soil until spring.

The application of foliar urea did not increase grain yields compared with the application of the $200 \mathrm{~kg} \mathrm{~N} \mathrm{ha}^{-1}$, suggesting that this rate was too high and that the yields obtained were too low to optimize the late $\mathrm{N}$ application. These results suggest that increases in grain yield following late-season urea applications were found only when previous $\mathrm{N}$ applications were insufficient to obtain maximum yield (Gooding and Davies, 1992; Gooding et al., 1997). No significant response of specific weight was found in these experiments, suggesting that the lowest topdressed $\mathrm{N}$ rate of $100 \mathrm{~kg} \mathrm{ha}^{-1}$ was high enough to obtain a high specific weight.

The average grain yields obtained in these experiments (between $2117 \mathrm{~kg} \mathrm{ha}^{-1}$ and $5551 \mathrm{~kg} \mathrm{ha}^{-1}$ ) are considerably lower than the 8000 to $10000 \mathrm{~kg} \mathrm{ha}^{-1}$ reported from central Europe. This region has a longer growing season, possibly higher amounts of intercepted solar radiation, better rainfall distribution and milder temperatures during grain filling than the Ebro Valley (Dilz, 1988; Clare et al., 1993).

The spike density went from 305 spikes $\mathrm{m}^{-2}$ in Bell-1loc in 1995 to 434 spikes $\mathrm{m}^{-2}$ in the same location in 1996. The lower amount of spikes $\mathrm{m}^{-2}$ observed in our trials, compared with reports from central Northern Europe (Ellen, 1990; Gate, 1995; Laloux et al., 1980), is probably related to the production features of Mediterranean systems. These are characterized, apart from the Mediterranean climate peculiarities, by the use of the Mediterranean type of wheat that normally has a lower tillering capacity and shorter growing season (Slafer and Whitechorch, 2001).

\subsection{Determination of quality}

Grain protein increased with increasing $\mathrm{N}$ fertilization rates but this response was only important in the location with a lower $\mathrm{N}$ level on the soil at sowing (Fig. 3, Tab. III). In Torregrossa grain protein increased from $12.4 \%$ to $15.8 \%$ (this is an increase of 27\%), whereas in Bell.1loc the increase was from $15.8 \%$ to $16.6 \%$. In our experiments the increase in grain protein was higher than that of the grain yield.

The grain protein contents of these trails were higher than the $12.7 \%$ or the $13.4 \%$ obtained in similar areas in 1997 and 1998, with a similar type of wheat (Lloveras et al., 2001). These large variations in grain protein contents seem to coincide with the results of Borghi et al. (1997), who reported that the climatic conditions of the Mediterranean areas may cause large fluctuations in grain protein content and in the rheological properties of the dough. In our study, even if locations are only separated by $10 \mathrm{~km}$, location also affected the quality of the wheat and Bell-1loc produced wheat of higher quality than Torregrossa, probably because of the higher soil nitrate levels of the first location.

In Torregrossa grain protein, sedimentation volume tests (SDS) and dough strength (W) were higher in 1996 than in 1995 (Tab. III, Fig. 3). This response was opposite to that found for grain yield. The higher quality obtained in 1996 was probably caused by the good growing conditions after sowing. In Bell.lloc, grain yield and dough strength were also higher in 
Table III. Statistical significances of grain yield and quality parameters: grain protein, sedimentation volume test (SDS), dough strength (W), dough resistance (P) and dough extensibility (L) alveograph of bread wheat.

\begin{tabular}{|c|c|c|c|c|c|c|c|c|c|c|c|c|}
\hline \multirow{3}{*}{$\begin{array}{l}\text { Treatments } \\
\text { and } \\
\text { Statistics }\end{array}$} & \multirow{2}{*}{\multicolumn{2}{|c|}{ Grain Yield $\left(\mathrm{kg} \mathrm{ha}^{-1}\right)$}} & \multirow{2}{*}{\multicolumn{2}{|c|}{ Grain Protein $(\% \mathrm{DM})$}} & \multirow{2}{*}{\multicolumn{2}{|c|}{ SDS Sediment (mL) }} & \multicolumn{6}{|c|}{ Alveograph } \\
\hline & & & & & & & \multicolumn{2}{|c|}{$\mathrm{W}\left(\times 10^{-4} \mathrm{~J}\right)$} & \multicolumn{2}{|c|}{$\mathrm{P}(\mathrm{mm})$} & \multicolumn{2}{|c|}{$\mathrm{L}(\mathrm{mm})$} \\
\hline & 1995 & 1996 & 1995 & 1996 & 1995 & 1996 & 1995 & 1996 & 1995 & 1996 & 1995 & 1996 \\
\hline & \multicolumn{12}{|c|}{ Torregrossa } \\
\hline \multicolumn{13}{|l|}{ Variety (V) } \\
\hline Bancal & 4731 & 2181 & 14.7 & 14.9 & 12.7 & 14.3 & 271 & 324 & 72 & 93 & 93 & 89 \\
\hline Rinconada & 3739 & 2053 & 13.8 & 14.2 & 9.1 & 10.4 & 252 & 282 & 92 & 89 & 75 & 82 \\
\hline \multicolumn{13}{|l|}{ Significance } \\
\hline Nitrogen $(\mathrm{N})$ & $*$ & $* *$ & $* *$ & $* *$ & $* *$ & $* *$ & $* *$ & $* *$ & NS & NS & NS & $* *$ \\
\hline V & $* *$ & $*$ & $* *$ & $* *$ & $* *$ & $* *$ & NS & $* *$ & $* *$ & NS & $* *$ & NS \\
\hline \multirow[t]{2}{*}{$\mathrm{V} \times \mathrm{N}$} & NS & NS & NS & NS & NS & NS & NS & NS & NS & NS & NS & $* *$ \\
\hline & \multicolumn{12}{|c|}{ Bell·lloc } \\
\hline Variety (V) & & & & & & & & & & & & \\
\hline Bancal & 3082 & 5857 & 17.3 & 16.7 & 14.6 & 14.7 & 288 & 403 & 80 & 92 & 80 & 118 \\
\hline Rinconada & 2724 & 5245 & 16.5 & 15.1 & 10.4 & 10.3 & 250 & 285 & 89 & 90 & 72 & 95 \\
\hline \multicolumn{13}{|l|}{ Significance } \\
\hline Nitrogen $(\mathrm{N})$ & NS & NS & NS & $*$ & NS & NS & NS & NS & NS & NS & NS & NS \\
\hline $\mathrm{V}$ & $* *$ & $* *$ & $* *$ & $* *$ & $* *$ & $* *$ & $*$ & $* *$ & $* *$ & NS & NS & $* *$ \\
\hline $\mathrm{V} \times \mathrm{N}$ & NS & NS & NS & NS & NS & NS & NS & NS & NS & NS & NS & NS \\
\hline
\end{tabular}

*,** Significant at the 0.05 and 0.01 probability levels, respectively. NS, not significant at the 0.05 level.

1996. However, late season rainfall can cause a relative grain protein dilution by extending leaf life and maintaining photosynthesis and carbohydrate translocation to the grain (Taylor and Gihmoun, 1971). In our study yield and quality increased together in Torregrossa and the grain yield increases did not affect the quality of the wheat. Higher dough strength (W) was mainly due to the increase in dough extensibility (L) and not to changes in $\mathrm{P}$. This is in agreement with research previously conducted under Mediterranean conditions (Borghi et al., 1997; López-Bellido et al., 1998; Lloveras et al., 2001).

The results of this research shows that the amount of protein, conferring good baking potential, increases with the $\mathrm{N}$ application rate, in agreement with others (Gooding and Davies, 1997; Stone et al., 1999; Triboï et al., 2000). The protein and dough strength $(\mathrm{W})$ values of the studied cultivars are in the upper range of the high bread-making quality wheat cultivated in Italy (Borghi et al., 1997), France (Gate, 1995) and Spain (AETC, 1997). Our results coincide with the second phase response to $\mathrm{N}$ fertilization reported by Stone and Savin (1999), which is, that additional $\mathrm{N}$ fertilizer will often have reduced (but positive) effect on starch accumulation and a proportionally greater impact on protein accumulation. Debaeke et al. (1996) in Southern France also reported that winter bread wheat grain yield and grain nitrogen concentration could be increased together through appropriate management. Our results suggest that in our conditions $\mathrm{N}$ was not a limiting factor in grain yield and in grain protein content.

Significant positive correlations (data not shown) between $\mathrm{N}$ per spike and grain number $\mathrm{m}^{-2}$ were obtained in both locations, suggesting that in our case the accumulation of $\mathrm{N}$ in the grain was not source-limited (Lloveras et al., 2004), possibly due to the relatively low yields obtained and the high soil nitrate contents of our trials. On the other hand, the application of $50 \mathrm{~kg} \mathrm{~N} \mathrm{ha}^{-1}$ of foliar urea at the flag leaf stage did not increase protein content and $\mathrm{W}$ values, compared with the application of the $200 \mathrm{~kg} \mathrm{~N} \mathrm{ha}^{-1}$ (Fig. 1), suggesting that this rate was too high to obtain any improvement of late application of urea at the production levels of these trials. The overall results of this research show that $\mathrm{N}$ fertilization can increase wheat quality even in areas that traditionally produce high-quality wheat and in soils with high soil nitrate contents.

\subsection{Residual soil nitrate}

$\mathrm{N}$ fertilization significantly increased soil nitrogen content in both years and sites (Fig. 1, Tab. IV) and the results suggest that in our conditions, the amount of $\mathrm{NO}_{3}^{-} \mathrm{N}$ present in the soil after harvest is quite significant, in the order of 400 to $600 \mathrm{~kg}$ $\mathrm{NO}_{3}^{-} \mathrm{N} \mathrm{ha}^{-1}$ in Bell.lloc and 80 to $120 \mathrm{~kg} \mathrm{NO}_{3}^{-}-\mathrm{N} \mathrm{ha}^{-1}$ that can be leached out of the soil or can remain in the soil until the sowing of the next crop, depending on the summer and autumn weather conditions. In the growing season of 1995-96 the rainfall in December and January was very high for our conditions (218 mm) (Fig. 1) and consequently there were losses of $\mathrm{N}$, probably related to leaching or denitrification, and not all the residual $\mathrm{N}$ in July 1995 was available for the rest of the growing season (1995-96).

These results suggest than when making $\mathrm{N}$ recommendations in Mediterranean conditions, where winter and summer rainfall is normally low, it is still important to analyze soil nitrogen reserves at the beginning of and during the growing season to adjust the $\mathrm{N}$ fertilization to the amount of soil $\mathrm{N}$ reserves. 


\section{Grain Yield (kg ha $\left.{ }^{-1}\right)$}

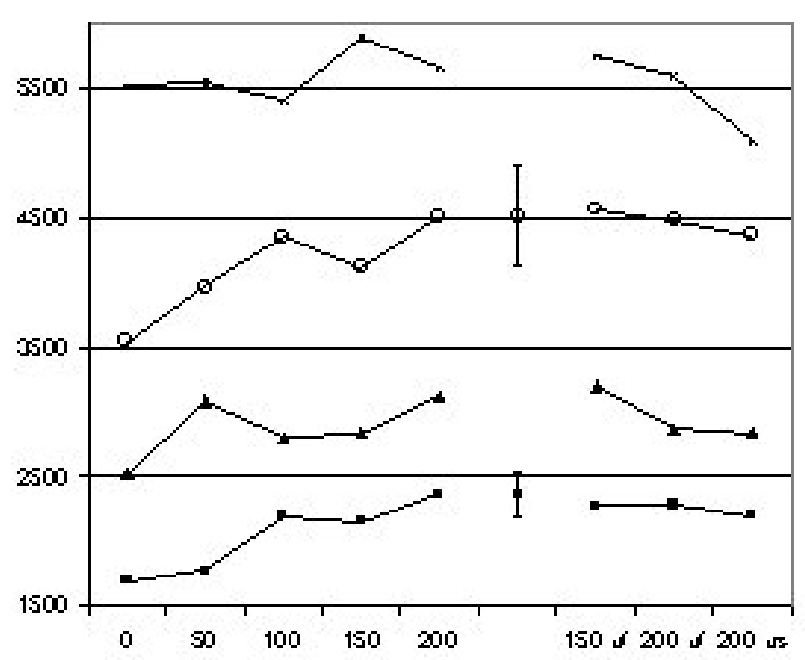

$W\left(\mathrm{~J} 10^{-4}\right)$

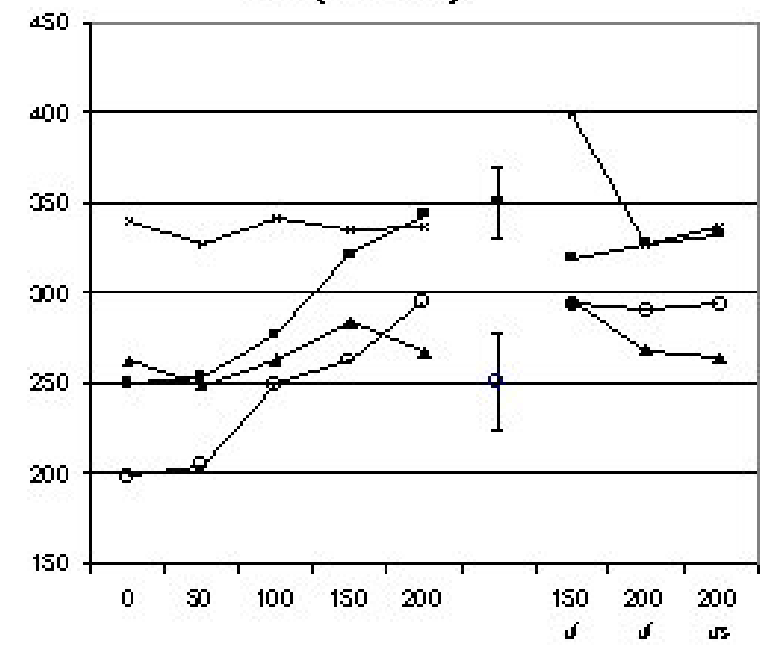

Grain Protein (\%DM)

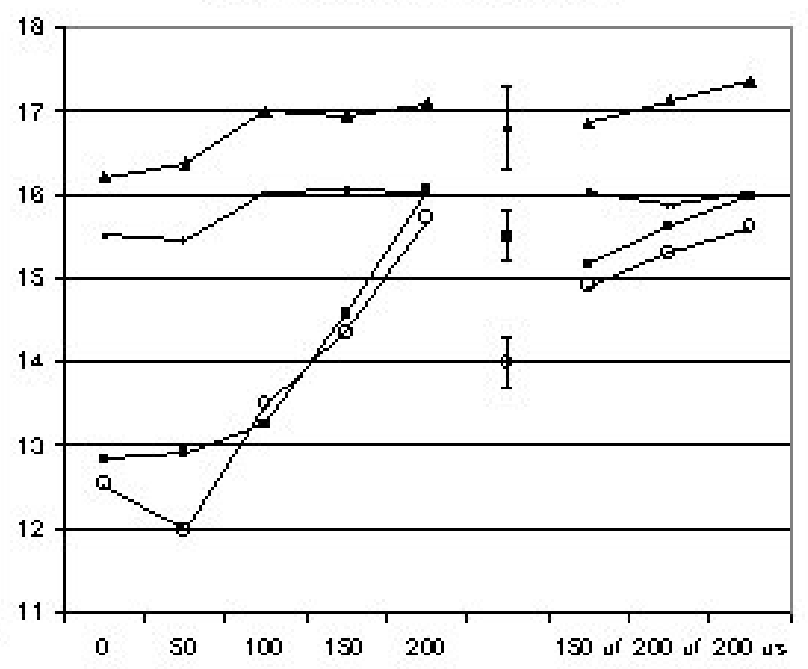

$0-90 \mathrm{~cm} \mathrm{NO}_{3} \mathrm{~N}\left(\mathrm{~kg} \mathrm{ha}^{-1}\right)$

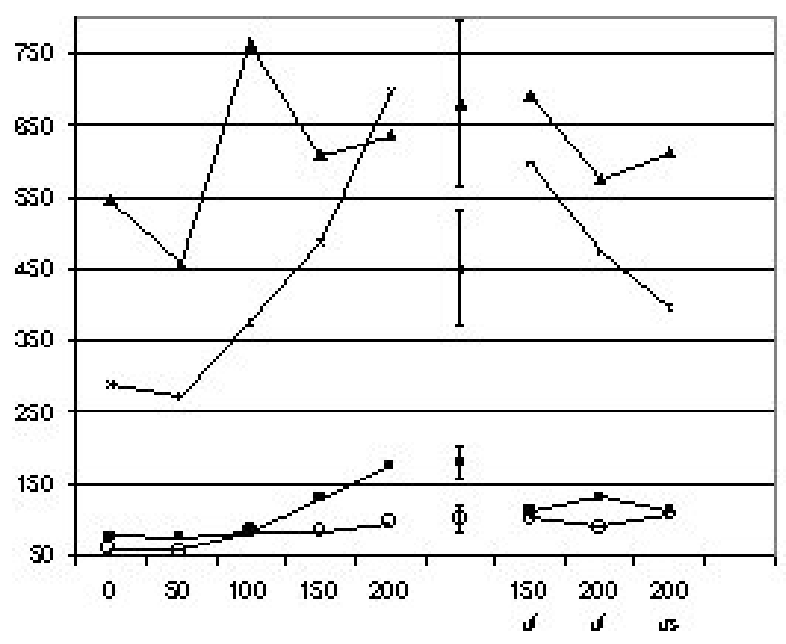

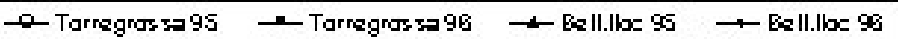

Figure 3. Effect of $\mathrm{N}$ fertilization on grain yield, grain protein, dough strength $(\mathrm{W})$ alveograph, and soil $\mathrm{N}$ content. In two $\mathrm{N}$ treatments (150 uf and $200 \mathrm{uf}$ ), the $\mathrm{N}$ was applied at seeding $\left(50 \mathrm{~kg} \mathrm{ha}^{-1}\right)$, at the flag leaf stage (50 kg ha ${ }^{-1}$ as a urea foliar spray) and the balance at tillering. In the last treatment (200 us), $\mathrm{N}$ was applied as mentioned in the preceding except that the $50 \mathrm{~kg} \mathrm{~N} \mathrm{ha}^{-1}$ flag leaf application was applied to the soil. Vertical bars indicate mean standard error of difference.

uf: Foliar-applied urea.

us: Soil-applied urea.

\section{CONCLUSION}

The results confirm the suitability of Mediterranean-type wheat and the Mediterranean climate for the production of good bread-making quality wheat, with high protein and dough $\mathrm{W}$ values, although grain yields tend to vary. Under these conditions, grain yield increases were mainly due to an increase in the number of grains $\mathrm{m}^{-2}$ without a reduction in the $\mathrm{N}$ content per spike, suggesting that $\mathrm{N}$ in the grain was not source-limited, possibly due to the low grain yields and relatively high soil nitrate concentrations. $\mathrm{N}$ fertilization increases yield only in low soil nitrate soils, showing that, in the Mediterranean areas of low yields, soils with high $\mathrm{NO}_{3}^{-} \mathrm{N}$ can supply most of the nitrogen needed by the crop. On the other hand, in the same period grain quality increased with $\mathrm{N}$ applications, even in soils with high $\mathrm{NO}_{3}^{-} \mathrm{N}$ levels. In other words, grain yield reaches a plateau with a lower application of $\mathrm{N}$ than wheat quality parameters do. A global appreciation of the grain yield, grain quality and residual soil nitrate of this research suggests that it is not possible to give a global recommendation. However, in soils with lower initial soil $\mathrm{NO}_{3}^{-} \mathrm{N}$ content, better grain yield results could be achieved by applying an $\mathrm{N}$ fertilizer rate of about 
Table IV. Contents of mineral nitrogen $\left(\mathrm{NO}_{3}^{-} \mathrm{N}\right)$ after harvest.

\begin{tabular}{|c|c|c|c|c|c|c|c|c|}
\hline \multirow{5}{*}{$\begin{array}{l}\text { Treatments } \\
\text { and } \\
\text { statistics }\end{array}$} & \multicolumn{6}{|c|}{ Soil depth } & \multirow{2}{*}{\multicolumn{2}{|c|}{ Total }} \\
\hline & \multicolumn{2}{|c|}{$0-30 \mathrm{~cm}$} & \multicolumn{2}{|c|}{$30-60 \mathrm{~cm}$} & \multicolumn{2}{|c|}{$60-90 \mathrm{~cm}$} & & \\
\hline & 1995 & 1996 & 1995 & 1996 & 1995 & 1996 & 1995 & 1996 \\
\hline & \multicolumn{8}{|c|}{$\mathrm{kg} \mathrm{N} \mathrm{ha}^{-1}$} \\
\hline & \multicolumn{8}{|c|}{ Torregrossa } \\
\hline 0 & 30 & 42 & 14 & 19 & 13 & 14 & 58 & 77 \\
\hline 50 & 34 & 45 & 13 & 16 & 9 & 15 & 57 & 76 \\
\hline 100 & 55 & 42 & 15 & 22 & 13 & 19 & 84 & 84 \\
\hline 150 & 41 & 76 & 22 & 32 & 19 & 20 & 83 & 129 \\
\hline 200 & 45 & 87 & 23 & 52 & 28 & 36 & 96 & 175 \\
\hline 150 uf & 51 & 59 & 20 & 27 & 28 & 19 & 100 & 112 \\
\hline 200 uf & 35 & 71 & 31 & 30 & 21 & 28 & 88 & 130 \\
\hline 200 us & 57 & 61 & 35 & 29 & 14 & 21 & 106 & 111 \\
\hline Average & 44 & 60 & 21 & 28 & 18 & 22 & 83 & 110 \\
\hline \multicolumn{9}{|l|}{ Significance } \\
\hline Nitrogen $(\mathrm{N})$ & $*$ & * & $* *$ & $* *$ & $* *$ & ** & $* *$ & $* *$ \\
\hline Variety (V) & NS & NS & NS & NS & NS & NS & NS & NS \\
\hline \multirow[t]{2}{*}{$\mathrm{N} \times \mathrm{V}$} & $*$ & NS & NS & NS & NS & NS & NS & NS \\
\hline & \multicolumn{8}{|c|}{ Bell·1loc } \\
\hline 0 & 200 & 98 & 153 & 45 & 167 & 145 & 545 & 290 \\
\hline 50 & 209 & 137 & 118 & 48 & 128 & 87 & 456 & 272 \\
\hline 100 & 275 & 148 & 339 & 86 & 147 & 139 & 762 & 375 \\
\hline 150 & 305 & 211 & 159 & 114 & 142 & 160 & 606 & 485 \\
\hline 200 & 283 & 320 & 118 & 148 & 138 & 228 & 636 & 697 \\
\hline 150 uf & 417 & 323 & 169 & 147 & 105 & 124 & 692 & 596 \\
\hline 200 uf & 283 & 204 & 144 & 127 & 145 & 141 & 574 & 473 \\
\hline 200 us & 392 & 181 & 104 & 85 & 114 & 129 & 611 & 396 \\
\hline Average & 308 & 203 & 163 & 100 & 135 & 144 & 612 & 448 \\
\hline \multicolumn{9}{|l|}{ Significance } \\
\hline Nitrogen $(\mathrm{N})$ & $* *$ & $* *$ & $*$ & * & NS & * & $*$ & $* *$ \\
\hline Variety (V) & NS & NS & $*$ & NS & NS & $*$ & $*$ & $*$ \\
\hline $\mathrm{N} \times \mathrm{V}$ & NS & NS & NS & NS & NS & NS & NS & NS \\
\hline
\end{tabular}

In two $\mathrm{N}$ treatments (150 uf and $200 \mathrm{uf})$, the $\mathrm{N}$ was applied at seeding $(50 \mathrm{~kg}$ $\left.\mathrm{ha}^{-1}\right)$, at the flag leaf stage ( $50 \mathrm{~kg} \mathrm{ha}^{-1}$ as a urea foliar spray) and the balance at tillering. In the last treatment (200 us), $\mathrm{N}$ was applied as mentioned in the preceding except that the $50 \mathrm{~kg} \mathrm{~N} \mathrm{ha}^{-1}$ flag leaf application was applied to the soil.

*,** Significant at the 0.05 and 0.01 probability levels, respectively. NS, not significant at the 0.05 level.

uf: Foliar-applied urea.

us: Soil-applied urea.

$100 \mathrm{~kg} \mathrm{~N} \mathrm{ha}^{-1}$, although this rate should be raised to $200 \mathrm{~kg} \mathrm{~N}$ $\mathrm{ha}^{-1}$ when maximum quality is needed. In soils with high initial $\mathrm{NO}_{3}^{-} \mathrm{N}$ contents, no $\mathrm{N}$ or a maximum rate of $50 \mathrm{~kg} \mathrm{~N} \mathrm{ha}^{-1}$ is needed in order to obtain a better grain quality and dough strength (W), an aspect that should be taken into account for the sustainability of the cropping systems. These amounts of $\mathrm{N}$ fertilizer are lower than those of previous reports from the area, showing the possibility of producing high-quality wheat with a low amount of $\mathrm{N}$ fertilizer, thus increasing the sustainability of the cropping system.

Ackowledgments: This research was supported by La Paeria (Lleida City Council) and by CICYT (Spanish Ministry of Science and Technology). We express our gratitude to M. Bagà, A. López, J. Del Campo, J. Millera, J. Betbesé and R. Mestres for their field and laboratory assistance.

\section{REFERENCES}

Addiscott T.M., Whitmore A.P., Powlson D.S. (1992) Farming, fertilizers and the nitrate problem, C.A.B. International, Wallingford, UK.

AETC (1997) Encuesta de Calidad de los trigos españoles, Cosecha 1997, Asociación Española de Técnicos Cerealistas, Madrid, Spain.

Altman D.W., McCuistion W.L., Kronstad W.E. (1983) Grain protein percentage, kernel hardness, and grain yield of winter wheat with foliar applied urea, Agron. J. 75, 87-91.

Axford D.W.E., McDermott E.E., Redman D.G. (1979) Note on the sodium dodecyl sulphate test of breadmaking quality: comparison with Pelshenke and Zeleny tests, Cereal Chem. 56, 582-584.

Bischoff M.M., Hiar A.M., Turco R.F. (1996) Evaluation of nitrate analysis using test strips, Comparison with two analytical laboratory methods, Commun. Soil Sci. Plan. 27, 2765-2774.

Borghi B., Corbellini M., Minoia C., Palumbo M., Di Fonzo N., Perenzin M. (1997) Effects of Mediterranean climate on wheat bread-making quality, Euro. J. Agron. 6, 145-154.

Borghi B. (1999) Nitrogen as determinant of wheat growth and yield, in: Satorre E.H., Slafer G.A. (Eds.), Wheat. Ecology and Physiology of Yield Determination, Food Products Press, New York, pp. 6784.

Bremner J.M. (1965) Inorganic forms of nitrogen, in: Black C.A. (Ed.), Methods of soil analysis, American Society of Agronomy, Madison, WI, Agronomy 9, Part 2, pp. 179-237.

Campbell C.A., Myers R.J.K., Curtin D. (1995) Managing nitrogen for sustainable crop production, Fertil. Res. 42, 277-296.

Chaney K. (1990) Effect of nitrogen fertilizer rate on soil nitrate nitrogen content after harvesting winter wheat, J. Agr. Sci. (Camb.) 114, 171-176.

Clare R.W., Spink J.H., Laverick R.M., Bailey J. (1993) Factors affecting the quality of milling wheat produced in a high yield situation, Aspects Appl. Biol. 36, 241-250.

Corbellini M., Mazza L., Ciaffi M., Lafiandra D., Borghi B. (1998) Effect of heat shock during grain filling on protein composition and technological quality of breads, in: Braun H., Altay F., Kronstad W.E., Beniwal S.P., McNab A. (Eds.), Wheat: Prospects for Global Improvement, Kluwer Academic Publishers, Dordrecht, The Netherlands, pp. 213-220.

Debaeke Ph., Aussenac Th., Fabre J.L., Hilaire A., Pujol B., Thuries L. (1996) Grain nitrogen content of winter bread wheat (Triticum aestivum L.) as related to crop management and to the previous crop, Euro. J. Agron. 5, 273-286.

Dilz K. (1988) Efficiency of uptake and utilization of fertilizer nitrogen by plants, in: Jenkinson D.S., Smith K.A. (Eds.), Nitrogen Efficiency in Agricultural soils, Elsevier Applied Science, London, pp. 1-26.

Ellen J. (1990) Effects of nitrogen and plant density on growth, yield and chemical composition of two winter wheat (triticum aestivum L.) varieties, J. Agron. Crop Sci. 164, 174-183.

Frederick J.R., Bauer P.J. (1999) Physiological and numerical components of wheat yield, in: Satorre E.H., Slafer G. (Eds.), Wheat, Ecology and Physiology of Yield Determination, Food Products Press, New York, pp. 45-65.

Gate P. (1995) Ecophysiologie du blé, Tec \& Doc, Lavoisier, ITCF, Paris.

Gooding M.J., Kettlewell P.S., Hocking T.J. (1991) Effects of urea alone or with fungicide on the yield and breadmaking quality of wheat when sprayed at flag leaf and ear emergence, J. Agr. Sci. (Camb.) $117,149-155$. 
Gooding M.J., Davies W.P. (1992) Foliar urea fertilization of cereals: a review, Fertil. Res. 32, 209-222.

Gooding M.J., Davies W.P. (1997) Wheat production and utilization, CAB International, Wallingford.

Hay R.K., Walker A.J. (1989) An introduction to the physiology of the crop yield, Logman Scientific and Technical, New York.

Hobbs P.R., Sayre D. (2001) Managing experimental breeding trials, in: Reynolds E.H., Ortiz-Monasterio J.I., McNab A. (Eds.), Application of physiology to wheat breeding, CIMMYT, Mexico.

International Association for Cereal Science and Technology (1992) Method for using the Chopin alveograph, ICC Standard Method, No. 121, Vienna, Austria.

Kettlewell P.S., Juggins S.A. (1992) Can foliar application of nitrogen fertilizer to winter wheat reduce nitrate leaching? Aspects Appl. Biol. 30, 103-108.

Laloux R., Falisse A., Poelaert P. (1980) Nutrition and fertilization of wheat, Wheat Documenta Ciba-Geigy, Technical Monograph, Basle, Switzerland.

López-Bellido L., Fuentes M., Castillo J.E., López-Garrido F.J. (1998) Effects of tillage, crop rotation and nitrogen fertilization on wheatgrain quality grown under rainfed Mediterranean conditions, Field Crops Res. 57, 265-276.

Lloveras J., López A., Ferrán J., Espachs S., Solsona J. (2001) Breadmaking wheat and soil nitrate as affected by nitrogen fertilization in irrigated Mediterranean conditions, Agron. J. 93, 1183-1190.

Lloveras J., Manent J., Viudas J., Lopez A., Santiveri P. (2004) Seeding rate influence on yield components of irrigated winter wheat in a mediterranean climate, Agron. J. 96, 1258-1265

Martre P., Porter J.R., Jamieson P., Triboï E. (2003) Modeling grain nitrogen accumulation and protein composition to understand the sink/source regulations of Nitrogen remobilization for wheat, Plant Physiol. 133, 1959-1967.
Peña R.J., Amaya A., Rajaram S., Mujeeb-kazi A. (1990) Variation in Quality characteristics associate with some spring 1b/1R translocation wheat, J. Cereal Sci. 12, 105-112.

Readman R.J., Kettlewell P.S., Beckwith C.P. (1997) Application of N as urea solution: $\mathrm{N}$ recovery and $\mathrm{N}$ use efficiency, Aspects Appl. Biol. 50, 125-132.

Sarandón S.J., Gianibelli M.C. (1992) Effect of foliar sprayings of urea during or after anthesis on dry matter and nitrogen accumulation in the grain of two wheat cultivars of T. aestivum L., Fertil. Res. 31, 79-84.

SAS Institute (1996) SAS User's Guide: Statistics, Version 6.03, SAS Inst., Cary, NC.

Scharf P.C., Alley M.M., Lei Y.Z. (1993) Spring nitrogen on winter wheat: I. Farmer-Field validation of tissue test-based rate recommendations, Agron. J. 85, 1181-1186.

Slafer G., Whitechurch E.M. (2001) Manipulating wheat development to improve adaptation, in: Reynolds E.H., Ortiz-Monasterio J.I., McNab A. (Eds.), Application of physiology to wheat breeding, CIMMYT, Mexico.

Stone P., Savin R. (1999) Grain quality and its physiological determinants, in: Satorre E.H., Slafer G.A. (Eds.), Wheat, Ecology and Physiology of Yield Determination, Food Products Press, New York, pp. 85-120.

Taylor A.C., Gilmour A.R. (1971) Wheat protein predictions from climatic factors in southern New South Wales, Aust. J. Exp. Agr. Anim. Husband. 11, 546-549.

Triboï E., Abad A., Michelena A., Lloveras J., Ollier J.L., Daniel C. (2000) Environmental effects on the quality of two wheat genotypes: 1. Quantitative and qualitative variation of storage proteins, Eur. J. Agron. 13, 47-64.

Zadocks J.C., Chang T.T., Konzak C.F. (1974) A decimal code for the growth stages of cereals, Weed Res. 14, 415-421. 